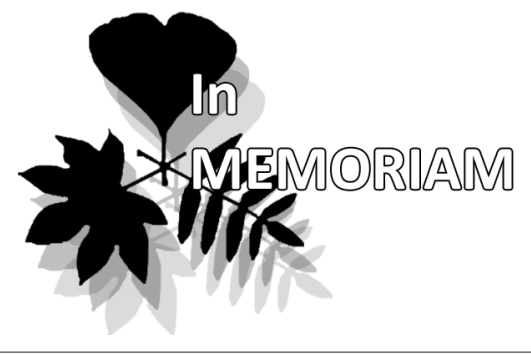

\section{Valentin Krassilov Memorial Article}

Katrina Krassilova

Katrina Krassilova graduated from Moscow State University with a diploma in English Philology and subsequently completed her Doctorate degree in Linguistics in the United States at the University of Florida. She presently teaches at Stetson University in Orlando, Florida

\section{Красилова Е.В. Валентин Красилов, воспоминания}

The Fairy tales speak of a mystical land far, far away where certain extraordinary events take place. Yet few people know that the land of "far away" really does exist. It is officially called the Far East and I know of it because I was born there in the town of Vladivostok. It was the secret town to which no foreigner was allowed to travel, not until 1989 when the first American navy ship entered and docked the port of Golden Horn the main harbor of Vladivostok. This was the beginning of the new era of foreign trade and travel. Until that time my father Professor Valentin Krassilov was unable to attend international conferences. In Soviet days it was difficult to travel outside of Russia in general, but out of Vladivostok, in particular, it was an impossibility. Those were the odds that my father had to overcome to establish international relations with paleobotanists, paleontologists, geologists, botanists all over the world and to become internationally known, and revered scientist. He reached out to scientists all around Russia to organize symposiums in Moscow, Ural, Ukraine and many other locations in Russia that he utilized not only because of Vladivostok's travel restrictions but as part of his endeavor to built bridges worldwide. Why was Vladivostok such a secret town? It was a military issue that our family had nothing to do with; yet we lived there so we had to suffer for it. Later in life father was able to attend conferences often as an honorary speaker and take part in expeditions in USA, United Kingdom, Italy, China, India, Middle East, Mongolia and other countries.

Many well-known scientists became not only his colleagues but lifelong friends, such as Professor David Dilcher from Indiana University in USA; the late Professor Jack Douglas of Melbourne, Australia; Hanna in the Netherlands; the famous paleontologist Phil Currie; Dr. David Butten in the United Kingdom and there were more friends that I am not able to name, as I have not had the pleasure of meeting them.

\title{
Valentin Abramovich Krassilov 1937-2015
}

Professor Valentin Krassilov spent the last years of his life working in Haifa, Israel, where he conducted research and lectured at the Institute of Evolution. Evolutionary theory had always been an important part of his research and writings. He published numerous books connecting paleobotany and evolutionary theory. Some of my favorite books that my father wrote are the 1986 "Unsolved Issues of Evolution" (fondly referred to in our lab as 'Nereshonka', which in English could be translated as 'Unsolvable'); "Evolution and Biostratigraphy" (1977); "Changes of Mesozoic Vegetation and the Extinction of Dinosaurs" (1981) and his last book "Evolution System Theory" (2014) that encompasses matters of evolution and philosophy. Father always hoped to reach out to broad audiences when writing his books and when teaching. He took his teaching to heart and was genuinely concerned if he felt that his students were distracted. He took too much to heart, which likely contributed to his untimely death from heart failure.

I was able to visit father with my little daughter two years before his death in Israel. He took us to many historic sites in Haifa area and to Holy places, such as the very lake where Jesus Christ used to go fishing and where Jesus walked on the water. My father was always delighted to see his granddaughter grow healthy and bright, and even asked me to take photos of her my daughter named Joleen for his last book. He put these photos in his book to illustrate some of his ideas on evolution. On the photo that appeared on the cover of the book: Joleen is running with a scepter in her hand, dressed as the Red Queen from Alice in Wonderland.

I, perhaps unfortunately, did not chose the field of paleobotany as my profession, though I often accompanied my father on his numerous expeditions to collect fossils. I also worked for a period of time as an assistant in his laboratory and came to meet many of his colleagues back home in Vladivostok: Dr. Evgenia Bugdaeva, Dr. Valentina Savishna Markevich, Klava, Inna, Nina, Natasha and, of course, Dr. Nadezhda Blokhina who is now in charge of the laboratory that my father used to lead. Those were his close friends who shared everyday hardships with good sense of humor and positive attitude to life. For me it was a pleasure to work with them, to go on field trips and conferences with them, to get to know them, as well as many other colleagues of my father all over the world. My mother Lidia Sokur father's first wife also worked at the laboratory. Professor Krassilov spent many years of his life building a vast collection of fossil samples from the Far East that he analysed in his works such as "Stratigraphy of the volcanogenic Cretaceous of the Soviet 
Krassilova, Zavialova, Sokolova, Maslova, Polevova, Tekleva, Volkova, Karasev, Gordenko, Bugdaeva, Markevich, Volynets, Cherepanova, Blokhina, Akhmetiev, Heth, Boucot, Nichols

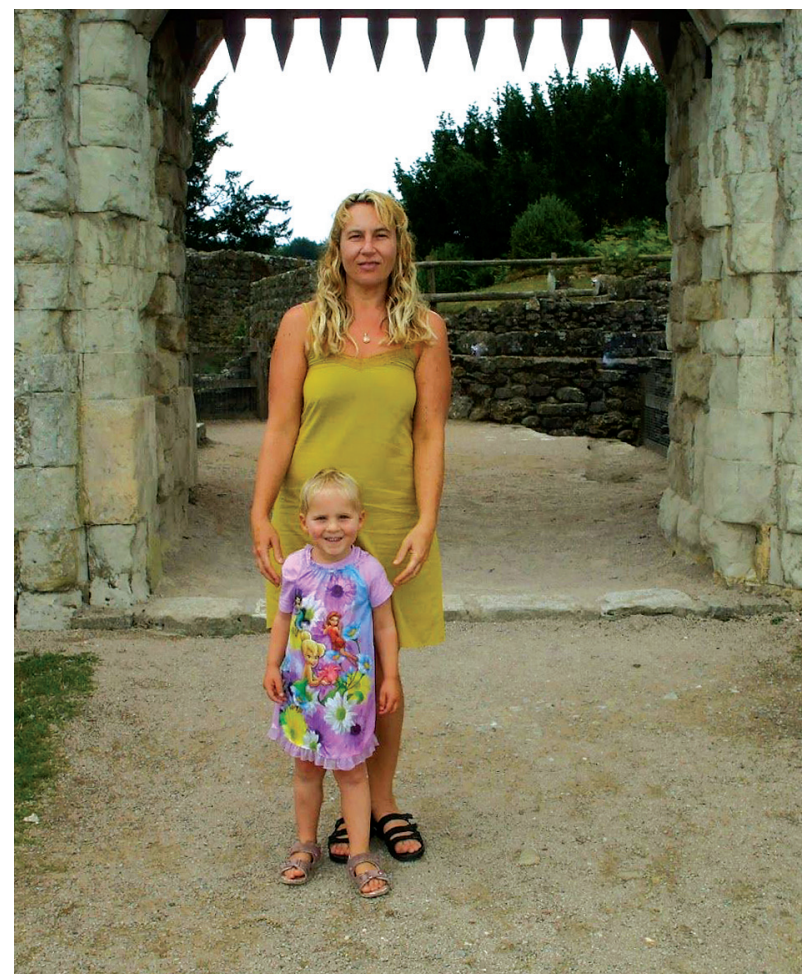

Katrina Krassilova with daughter Joleen

Far East" (1987). He later expended his collection that now reflects all of his worldwide expeditions.

Professor Valentin Krassilov's scientific work is well known. It is, perhaps, less known that he had a wide range of interests in the fields of literature, history and philosophy. There was not a work of literature that my father hasn't read, no period of history that he was not familiar with, and no philosopher that he would leave undiscovered. I was working on my Doctorate dissertation at the University of Florida, studying the writings of a medieval knight Sir Thomas Malory. My father helped me with the analysis of Malory's philosophy, as it took a great deal of knowledge of ancient and medieval philosophy to understand Malory's input. Then a few years ago I began writing a book on the life of British explorer George Mallory who pioneered Everest exploration. I considered George to be the successor of the medieval Knight Malory. My father found the subject fascinated and shared his thoughts on it with me. Mallory died on Mount Everest leaving behind him a mystery of whether he was the first to reach the summit of Everest or he died on the ascend. What interested us the most in the story, was the inspiration behind such an endeavor. Why George Mallory, a school teacher from a small town in England, happily married with three small children, would take upon himself the conquest of the tallest mountain in the world where temperatures are far below freezing and oxygen is lacking. It is known that Mallory carried the picture of his wife Ruth on his expeditions and wished to place the picture on the summit of Everest. My father's words on the sentiment were the following: Is it, perhaps, through Everest that Mallory was making his way to the heart of Ruth? I, at first, did not quite follow his point of view. Mallory was married to Ruth for many years; he had children with her. So was such extraordinary proof of love really necessary? And Ruth would have likely much prefered that Mallory stayed home with her. Yet later I came to realize that my father had a better understanding of a mind of a hero. Heroes care little about what is necessary in a practical sense, nor of other people's expectations of them, or even of the cost of it all. They answer to a higher calling. They climb the tallest mountain simply "because it is there". Much like George Mallory taking a whack at icy boulders with his

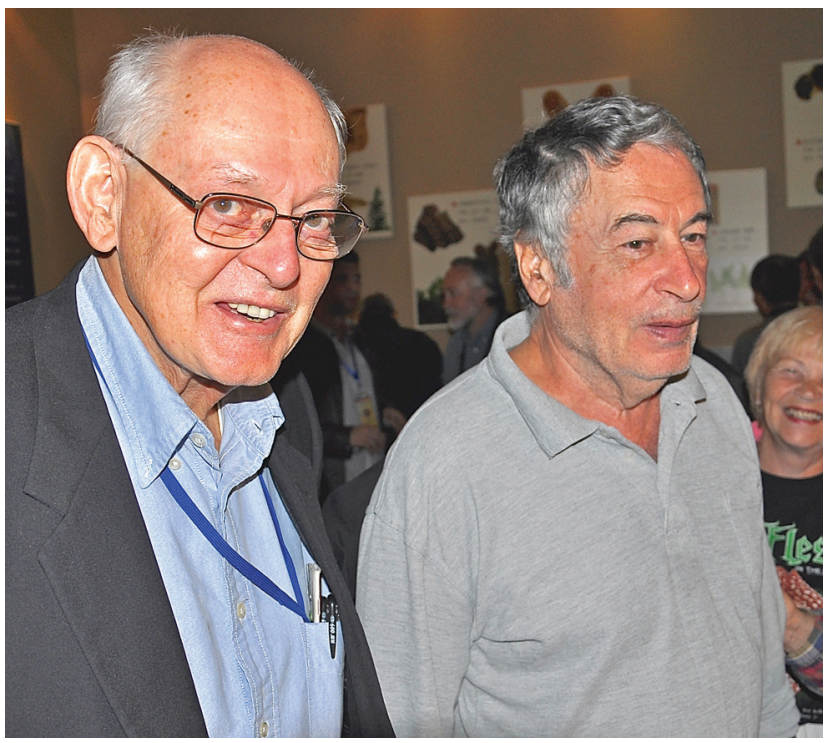

ice axe, my father took boulders apart with his giant axe at a dig in search of fossils. My father too was an ardent explorer.

Dr. Valentin Krassilov organized expeditions to untraveled, remote, often unpopulated locations. Oftentimes, these were places with no hotels, no tourists, no restaurants nothing but vast wilderness. He often took me with him on his expeditions when I was a little girl. We braved endless weather delays at the airport of Vladivostok (due to severe climate of the Far Eastern corner of Russia); we spent nights in overlays at Khabarovsk airport the inevitable overlay spot for all those traveling in and out of Vladivostok.

To give an idea of just how far the Far East really is: it takes longer to fly from Moscow to Vladivostok than to fly from Moscow to New York. But the planes were only the beginning of the journey; for the most part we traveled on foot father carrying backpacks loaded with tents, sleeping bags and provisions. And at the end of every expeditions he carried backpacks filled with fossil samples that were of course as heavy as rocks, because those were, in fact, rocks.

Sometimes father employed rather unconventional methods of transportation. Once on our way to Kuril islands we sailed aboard a crab fishing vessel because it was the only way to reach such a remote and largely unknown location. Crab fishermen generally do not carry passengers and they are not always the friendliest kind. Yet father carried with him a bottle of vodka just for such occasions to insure successful negotiations. After sampling our vodka the fishermen confessed that they at times engage in piracy under the cover of thick fog of the sea of Japan. There was nothing but a military base in Kuril islands. And the only methods of transportation that the military stationed there had access to were a helicopter, a tank and horses. The soldiers and officers were happy to share with us all of the above and even to show us around the island and warn us of the dangers out there. The tides come quick and violent, making the strip of beach vanish under the stormy waters. If cut off from the beach, one would be forced to walk a narrow, uneven path along the tall cliffs. Extreme gusts of winds are capable of causing severe damage and we were told that several men had fallen off the cliffs because of those sudden strong wind gusts. Those kind of wind gusts are also likely to cause catastrophic Tsunami waves that plague the coastal cities of Asia. Yet despite the dangers, we enjoyed our trip to Kuril islands father and I always liked riding horses and we also had very good meals there. While we were out exploring, our camp was attacked by a family of wild boars and our own provisions were destroyed. We had to temporarily move into the barracks. The soldiers stationed there seemed to live on a diet of seafood and shared with us freshly caught crab and scallops. On our way back to civilization we got a ride 


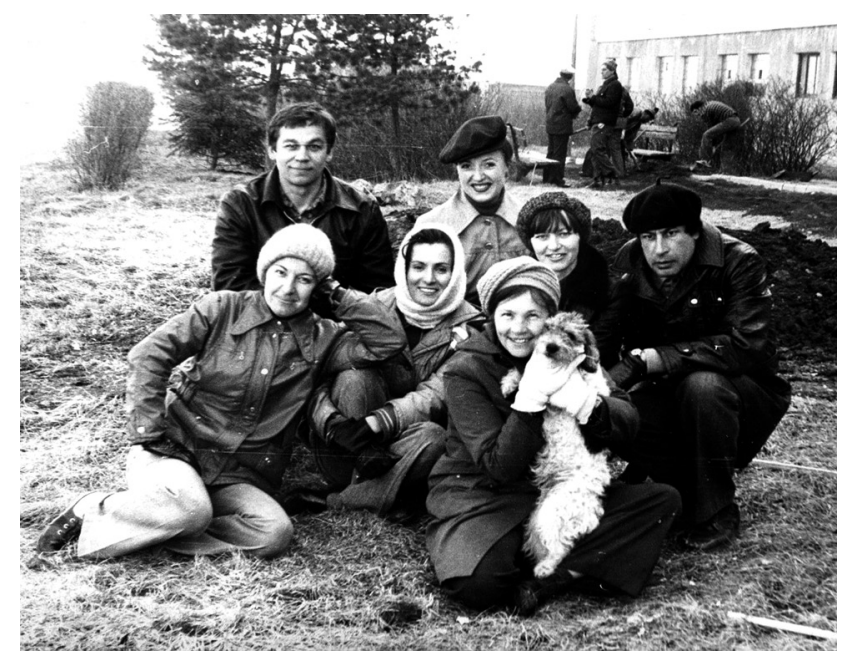

His first lab of Paleobotany in the Institute of Biology and Soil Sciences, Vladivostok, Russia. Saturday free labour day (subbotnik), a mandatory soviet holiday, is used for team building. Left to right: Nina Domra, Alexander Kundyshev, Natalia Verkhovskaya, Nadezhda Blokhina, Valentina Markevich, Claudia Novikova, Valentin Krasilov

on another fishermen's boat this one carrying seaweed. The fishermen pulled seaweed with giant nets, then piled it right on the deck and all over it. I still have strange dreams of wading knee deep in seaweed when aboard that ship. The Far East is wellknown for its variety of seaweed dishes. There is seaweed and calamari, seaweed and carrots, seaweed and clams with clam sauce (my favorite) and on lean days one can always make a meal out of plain seaweed.

Our trip to Sakhalin was something of a survivor experience as well. The entire area of Sakhalin island is covered by dense forest and we had an encounter with a wolf when passing through the woods. There was also evidence of bear presence near our camp, as bears are numerous in that area of Russia. The climate is similar of that in Siberia, though we were there in the summer and even were able to take a dip in the icy waters of Okhotsk sea. We walked through Siberian tundra, visited Lake Baikal the largest lake in the world and climbed the mountains of Ural, where it was snowing, oddly enough, in May, when roses were already in full bloom. There were expeditions to warmer parts of Russia as well, such as Crimea, on the Black Sea. In the USA I accompanied father on his trips to conferences to Nevada and Missouri (I was already grownup by then). This was the time when I did all the driving and no one, of course, was safe. Yet we were very much blessed as all of our expeditions were successful.

The scientific reflection of the trips can be found in the books that my father had written, such as "Cretaceous Flora of Sakhalin" (1979), "New Floral Structure from the Lower Cretaceous of Lake Baikal Area" (1986) and an article "Achene-Like Fossils from the Lower Cretaceous of the Lake Baikal Area (V.A. Krassilov, E.V. Bugdaeva, 1982). Father published this article with Dr. Evgenia Bugdaeva who accompanied him on the expedition to Lake Baikal and many other trips as well.

Dr. Krassilov had his own valuable theory on recent global anticipations of catastrophic climate change that we often hear discussed in the news. Valentin Krassilov published several works on climate changes such as his book entitled "Terrestrial Paleoecology and Global Change" (1994) and his article "Reflections on the Relationship Between Phytogeography, Climate and Evolution" (2003).

My father during his lifetime published over 143 scientific works, including 24 books in Russian and English. It seems to me that his last published book "Evolution System Theory" (Krassilov 2014) was of particular importance to him and he was very proud of it. The book contributes to the

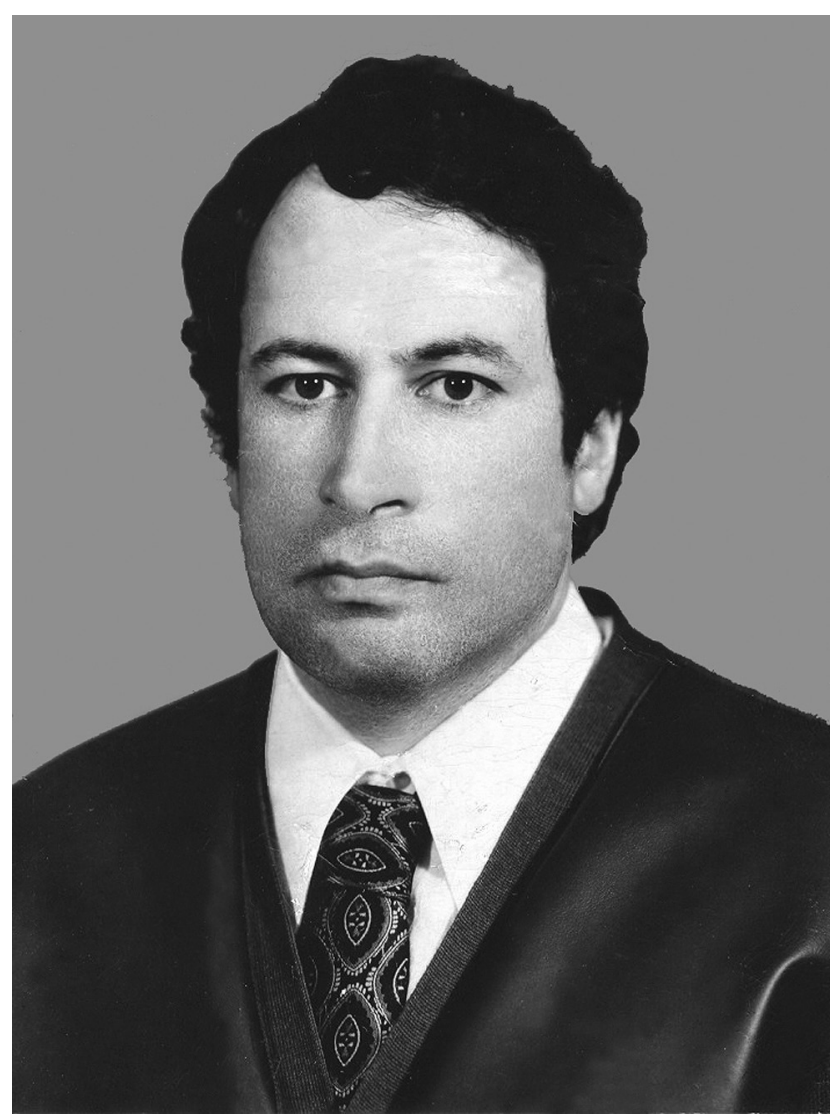

Valentin Krassilov. 1970s

theory of evolution and contemplates on the process of life and birth of life. "Life is a constructive effort", wrote my father, "the maintenance work of biological system on itself (feeding and reproduction, as well as cognition are the particulars of it) through which potential energy is replenished."

Life certainly was a constant constructive effort for my father. He was never idle. He encouraged myself and my daughter to avoid idleness so we too live a creative, constructive life. It is not by chance that I began this memorial article about my father as something of a fairy tale. Father enjoyed analyzing fairy tales, as well as works of literature and historical legends. Famous fairy tales survived the test of time as there is something in them that speaks to people from all periods of time from the dark ages where they had taken their root to modern times. They are being retold, now remade by filmmakers, but essentially they remain the same. When I was little I found the story of Little Red Riding Hood to be puzzling and terrifying. Why did the mother send her little daughter alone on that deathdefying journey into the woods? But it was not so much the encounter with the lone wolf in the woods that made the story so frightening to me. It was the later finding of the wolf in disguise the betrayal of the expected comfort of grandmother's home that I found particularly disturbing. Father's thoughts on the subject were that the story of the Little Red Riding Hood, perhaps, begun in the dark ages as, indeed, the horror story of a starving grandmother that consumed her own granddaughter. As I have always been sensitive to the true meaning of literary/creative work, even as a child I must have intuitively solved the origin of that legend, which is why I was so terrified by it. My eightyearold daughter Joleen, however, perhaps fortunately, does not possess my sensitivity to hidden meanings and finds Little Red Riding Hood entertaining and no more frightening than any of the fairy tales. Of course, all fairy tales like Cinderella, Sleeping Beauty or Snow White contain within them 
Krassilova, Zavialova, Sokolova, Maslova, Polevova, Tekleva, Volkova, Karasev, Gordenko, Bugdaeva, Markevich, Volynets, Cherepanova, Blokhina, Akhmetiev, Heth, Boucot, Nichols

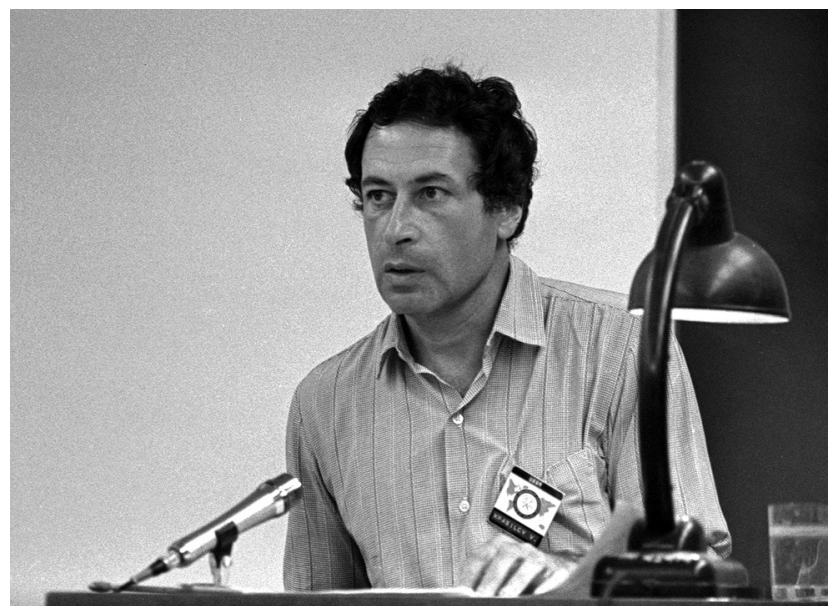

Valentin Abramovich presents a talk at XXVII Geological Congress, Moscow, 1984

an element of fear. And only truly fearless child like Joleen would have no nightmares after Beauty and the Beast (better known in Russia as "Scarlet Flower"). Alice in Wonderland is perhaps the most philosophical of all stories written for children. The photo of my little daughter Joleen that made the cover of my father's book is a metaphor from Alice in Wonderland Alice with the Red Queen attempting to outrun the time itself. It is also the metaphor of evolution. "For life as a whole is the Galactic whirlpool" and it is not a matter of chance that we all are in the same boat floating through the Universe (Krassilov 2014).

\section{Literature cited}

Krassilov, V.A. 1977. Evolution and Biostratigraphy. Nauka, Moscow, 256 pp. (in Russian). [Красимов В.А. Эволюция и биостратиграфия. М.: Наука, 1977. 256 с.].

Krassilov, V.A. 1979. Cretaceous flora of Sakbalin. Nauka, Moscow, 182 pp. (in Russian). [Красилов В.А. Меловая флора Сахалина. М.: Наука, 1979. 182 с.]

Krassilov, V.A. 1981. Changes of Mesozoic vegetation and the extinction of dinosaurs. Palaeogeography, Palaeoclimatology, Palaeoecology 34(3-4): 207-224.

Krassilov, V.A. 1986. Unsolved Problems of Evolutionary Theory. Dal'nauka, Vladivostok, 140 pp. (in Russian). [Красилов B.A. Нерешенные проблемы теории эволюции. ВАадивосток: АВНЦ АН СССР, 1986. 140 с.].

Krassilov, V.A. 1986. New floral structure from the Lower Cretaceous of Lake Baikal area. Review of Palaeobotany and Palynology 47(1-2):9-16.

Krassilov, V.A. (ed.) 1989. Volcanogenic cretaceous of the Far East. DVO AN SSSR, Vladivostok, 148 pp. (in Russian). [Вулканогенный мел Аальнего Востока / отв. реА. В. А. Красилов. ВАадивосток: $\triangle$ ВО АН СССР. 148 с.].

Krassilov, V.A. 1994. Reflections on the relationship between phytogeography, climate and evolution. Review of Palaeobotany and Palynology 83(1-3): 131-136.

Krassilov, V.A. 2003. Terrestrial Paleoecology and Global Change. Pensoft, Sofia, $464 \mathrm{pp}$.

Krassilov, V.A. 2014. Evolution: System Theory. Pensoft, Sofia-Moscow, Bulgaria, $414 \mathrm{p}$.

Krassilov, V.A., E.V. Bugdaevea 1982. Achene-Like fossils from the Lower Cretaceous of the Lake Baikal area. Review of Palaeobotany and Palynology 36(3-4):279-295.

Krassilova, E. 2006. The elect of Everest. Pensoft, Sofia, 176 pp. (in Russian). [Красилова Е. 1982. Избранник Эвереста. София: Пенсофт. 176 с.].

Zimmerman, Y. 2005. Female discourses: powerful and powerless speech in Sir Thomas Malory's LeMorte Darthur. Doctorate Dissertation. University of Florida, Gainesville, U.S.A. http://etd.fcla.edu/UF/ UFE0012949/zimmerman_y.pdf, last accessed 25.10.2015.

\section{Our Valentin Krassilov}

Natalia Zavialova ${ }^{1}$, Aleksandra Sokolova ${ }^{1}$, Natalia Maslova ${ }^{1}$, Svetlana Polevova ${ }^{2}$, Maria Tekleva ${ }^{1}$, Lyudmila Volkova ${ }^{1}$, Eugeny Karasev $^{1} \&$ Natalia Gordenko

${ }^{1}$ A.A. Borissiak Paleontological Institute, Russian Academy of Sciences, Moscow 117647, Russia

${ }^{2}$ Biological Faculty, M.V. Lomonosov Moscow State University, Moscow, Russia

Завьялова Н., Соколова А., Маслова Н., Полевова С., Теклева М., Волкова А., Карасев Е., Горденко Н. Наш Ваментин Красимов

The sudden shock from what happened on February 10, 2015 is gradually easing, and now students and colleagues of Professor Krassilov are able to reflect on their encounters with him. We consider ourselves fortunate to work with this outstanding scientist and mentor, and to bear witness to depth and vibrancy of his ideas. We would like to share with the readers our perceptions of him - as a scientist and a person. Each of us remembers his or her own "Krassilov"; these are feelings of deep gratitude that unite all our memories.

\section{Natalia Maslova:}

The laboratory of paleobotany was established at the Paleontological Institute in 1994, and Valentin Krassilov became its first head. This event was important for the institute, which at that time encompassed only zoological laboratories, whereas few scientists studied fossil plants. Crucially for the new laboratory, a scientist with a worldwide reputation was invited to lead it. I was one of three paleobotanists who had already worked at the institute: we became the first members of the lab. We mostly studied the general morphology of fossil plants; and the research equipment we had was modest, to say the least. That was the starting point for Valentin, who was dedicated to hold paleobotany to the highest standards at the Paleontological Institute. He put his energy and enthusiasm to work acquiring modern research equipment and developing an intellectual environment; he invited paleobotanical students, who later grew into well-qualified specialists under his supervision.

I was not acquainted with him before his coming to the institute, but I had read his papers and understood that he was an outstanding scientist. I imagined him as some distant and unapproachable genius; it was difficult to comprehend that he would soon appear here in person. At that time, I had just resumed working after a long maternity leave with my second son. I was in doubt as to whether I would be able to work while raising my children. Such developments like a newly-founded lab and a new (and unusual) supervisor made me feel even more confused. I remember our first encounter clearly. A modestly dressed and young-looking man with a big briefcase entered the room. He introduced himself: "Valentin Krassilov." A new room that the administration had allocated for him was being renovated, and I invited him to use my desk temporarily. "Where do you work? Which desk is yours?" were his questions. Upon hearing the answers, he vehemently rejected my offer and instead occupied a tiny coffee table. I still remember what I felt sitting at a comfortable desk, whereas a genius was working at a table that was too small and low for him. The renovation of his office was soon finished, but this example of selflessness and his ability to remain dedicated and productive under any circumstances is still fresh in my memory.

Valentin once asked me why I still had not defended my doctoral thesis. I told him about my family, my children, and my rather poor health and explained that I had not done it at the proper time, and then it was difficult to find time for such a task. His answer was, "A good family is the most valuable thing in a person's life. As for your thesis, all you need to do is keep working each day. Let it be a very small step, but done each day, without holidays or days off. You will not notice how you accomplish the work!" I now see 


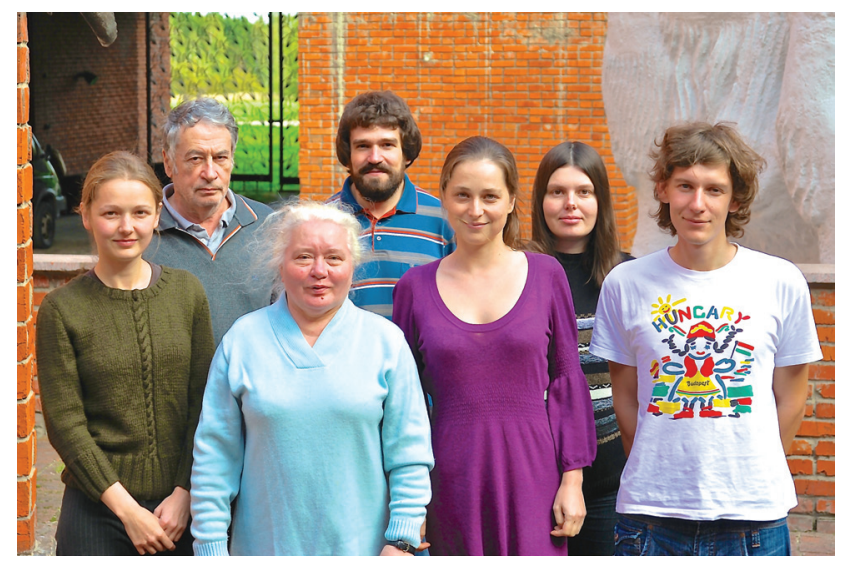

Valentin Abramovich and members of the Laboratory of Paleobotany, yard of the Paleontological Museum, Moscow, 2010. From the left to the right: Maria Tekleva, Valentin Krassilov, Lyudmila Volkova, Anatoly Broushkin, Natalia Zavialova, Natalia Gordenko, and Eugeny Karasev

that he was right: I did defend both of my theses. I am appreciative to Valentin for my scientific career, and I am infinitely grateful for his professional and collegial support.

He is warmly remembered by my family: my husband, who often conversed with him, and my sons, who are now adults and with whom Valentin liked to chat when they were little boys. We lived in the same neighborhood, and often returned home together. I recall our trolley bus trips, when he discussed new plans and shared his philosophical ideas. Many people thought Valentin to be a joyless person, who sometimes even appeared glum and cold. He was often deep in his thoughts; his brain was constantly working, and it was difficult for him to relax. I often managed to cheer him up. He had a great sense of humor, and responded generously to good conversation and fun.

Valentin was a good father; he loved his daughter Katya very much, always helping her in everything she did and felt great empathy for her problems. He was happy when his granddaughter Joleen was born; he rejoiced at her achievements: "she swims like a fish" and "she sings like an angel." Valentin was also a devoted and faithful son. When his elderly mother needed his care, he left Moscow and the laboratory he created and moved to Israel to be with her.

Three months before his death, he visited the Paleontological Institute, where he presented a talk at an anniversary conference of the Russian-Mongolian paleontological expedition, chatted with the lab people, described his new book, and planned a field trip to Mongolia for the 2015 field season. As always, he was full of strength, energy, and plans. I remember him briskly walking through the halls of the institute. People remarked, "Your boss is nearly flying."

His death was sudden: his heart stopped. He often reflected on the phenomenon of death and wrote about it in his philosophical papers. I once found a J.K. Rowling quotation that seemed so interesting to me that I showed it to Valentin, "To the well-organized mind, death is but the next great adventure." We jokingly agreed about the meeting place in that unknown world. Who knows what is beyond that door? Anyway, I remember the meeting place very well.

\section{Natalia Gordenko:}

My acquaintance with Valentin Abramovich Krassilov was a kind of miracle. When I entered the Department of Palaeontology at Lomonosov Moscow State University, I had already decided to study paleobotany, but suitable material for a course work was lacking. The only solution was to collect it myself. At that time, I was introduced to Valentin Abramovich who was looking for students for his newly created paleobotanical laboratory at the Paleontological Institute of the Russian Academy of Sciences. He

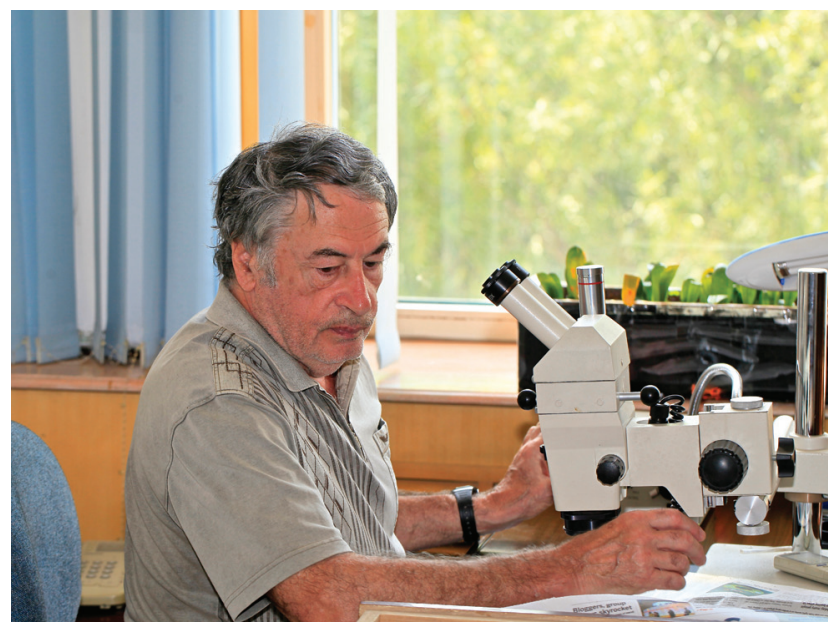

Valentin Abramovich in laboratory of Prof. Sun Ge, Changchun, China (2011)

invited me to attend a field trip to a new locality at the Peski quarry (Moscow vicinity), where, among other fossils, a Middle Jurassic flora was found. The material for my work was collected at this locality, and Valentin Abramovich took me under his wing. He was a difficult, but very interesting person. He was a virtuoso and fanatic for paleobotany. His style of work with the material was inimitable: he did not work, but practiced magic. Standing beside him at such moments, you felt like an alchemist's apprentice. Alchemists often had secrets which they concealed from everyone, but Valentin Abramovich concealed nothing. He passed on all his knowledge and experience to his students, sparing for them neither time nor effort. He was a unique teacher.

\section{Svetlana Polevova:}

Botanists of my generation became aware of Valentin Krassilov when we read classical monographs, and we fancied him somewhere together with Carl Linnaeus and Afrikan Krishtofovich. At first, we did not realize that he was a living legend, and we could see him in person at conferences. One could have more easily talked to him during field trips, whereas he appeared to be an unapproachable celestial being during plenary sessions. His insatiable desire for knowledge could have only been comparable to his observational acuteness where he could find the most interesting specimens even from localities that seemed to be thoroughly explored. The latter could have seemed like luck only later realizing it came from his rich experience and his prepared mind. VA (as we used to call him) enjoyed boggling listeners' minds with well-staged tricks. His talks left nobody indifferent. He knew how to generalize from a collection of trivial facts in a way that made mature morphologists and acknowledged taxonomists jump up in excitement, whereas VA remained calm, spoke in a low voice, and was open to discussions after his speeches about facts that seemed to contradict his hypotheses. He listened, but in response drew on his wide range of knowledge often presenting different ways of viewing those facts that would miraculously support his point of view. Over time, being associated with VA taught you to formulate and consider new hypotheses and new ways of considering data, than just the accepted versions and interpretations.

When you read literature, you always unconsciously look for your own thought expressed by other authors. The closer it is to your concept of a given phenomenon, the more you like it and want to share it with colleagues. To read VA's works is always thrilling. At first, you feel a total rejection and desire to dispute and disagree with everything. Paradoxically, the closer you are to the end of an article or a book chapter (provided you did not jump up from your 


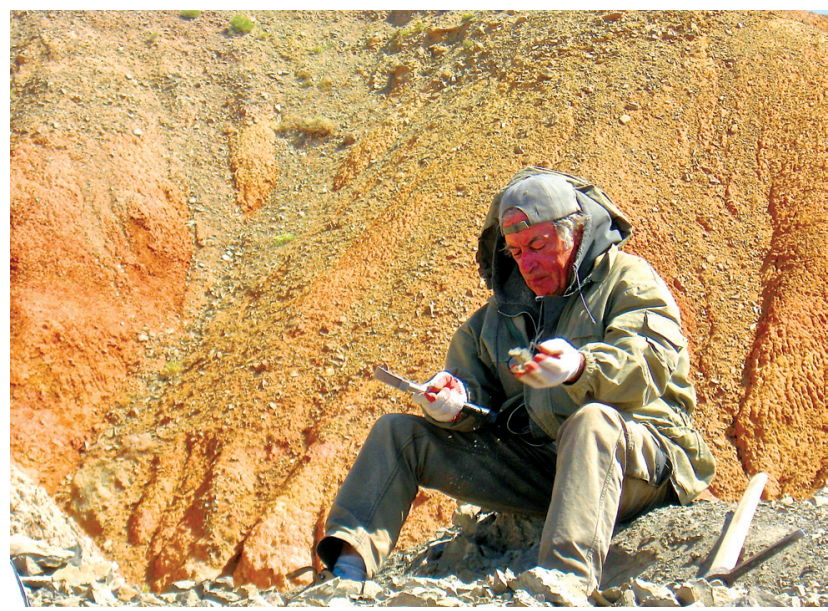

Valentin Abramovich is collecting fossil plants, Mongolia field-trip, 2008

chair and read to the logical conclusion), the stronger the perception that he might be right - or at least that he is on to something. You start pestering those around you by reciting the paradoxes or e-mailing them, if at the moment you are surrounded only by aquarium fish and African violets. If, when you are writing a routine paper and the conclusion fits well an existing opinion and dogma, and no problems are expected during the review process, then there will probably be no place to discuss thoughts earlier expressed by VA in the context of your data. However, if you are facing results that demand deeper reflection before they allow you to incorporate them into the framework or if you are able to come up with an ingenious interpretation, then you may suddenly discover that this paper is a very suitable occasion to cite VA. VA's books and articles stimulate thinking in the way that an artist often forces us to see mundane things from a brand new perspective.

\section{Natalia Zavialova:}

There is no doubt that VA influenced our professional lives. I still feel an impulse to convince and out-argue him; however, this intellectual pleasure is not possible anymore. There are many things that I still want to learn from him. Scientists are often judged by how prolific they are, our scholarly works are our intellectual currency and VA was prolific. How did he manage this being a lab director, scientist, friend and family man? How does he accomplish this and I do not, what is different in his work habits than mine, and is there any chance that I may adopt his style? Unlike me, VA was distinguished by his energy: he hit the ground running at the initial stage of an investigation and did not slow down to leisurely admire the obtained results at the final stage. As soon as he clicked the submit button, he switched to the next topic at full speed. I have not acquired this skill yet. However, I definitely remember that I worked faster and more effectively when he visited the lab; this was true even for projects that he did not participate in. In part, it was due to a competitive spirit. Another reason was the danger than he would do your work for you. VA liked to get into his students' and younger colleagues' heads; he filled their papers with his ideas. Therefore, so as not to lead VA into temptation and not become the coauthor of ideas that you did not reach through suffering, you had to stop lingering and finish the work sooner rather than later. They say some supervisors do not mind arrogating the achievements of their subordinates; it was just the opposite with VA.

VA was an adept strategist at writing grant proposals. Below is his special recipe for a grant proposal à la Krassilov. A virtually finished investigation, which is now in preparation or being submitted, should be put forward. Then, if the project is supported, the paper will be submitted or

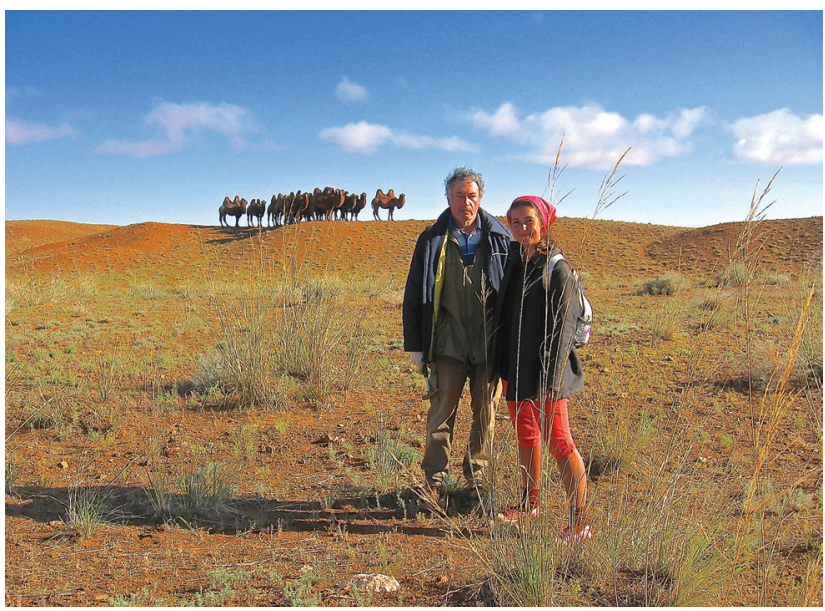

Valentin Abramovich and Aleksandra Sokolova during Mongolia field-trip, 2008

in press at the time the grant is received. Reviewers are impressed seeing articles issued in high-impact journals during the first year of the project. Besides, it is so easy to compose a working plan for a study already carried out, and one will never need to change it and substantiate the changes. This strategy fared well in the Russian scientific zeitgeist. For example, there will be no problems caused by a possible demand to state the journal name where the publication is planned. The awarded funds should immediately be spent for one or, even better, several new studies, which, in turn, will later become the basis for other proposals. The only trick is to maintain the pace, constantly staying ahead.

VA differed from most contemporaneous scientists in being a non-conformist often offering new and novel ideas. The value of this approach is scientific communication not only reports data and results, but also should inspire other scientists to question all interpretations and even entertain novel ideas. Although many of VA colleagues may have questioned his hypotheses, nonetheless, they all had to thoughtfully consider them whether they agreed or not. I am no exception to this feeling. To make VA change his mind was a challenge. Good ideas sometimes came to mind through this proof by contradiction, and otherwise they did not appear. The incident below shows that this did not happen only to me but to others as well.

Once, I was a final reviewer of a paper written by VA and coauthors. The editor asked me to evaluate how the authors revised the manuscript according to the suggestions of the reviewers, because he needed to decide whether to accept or reject the paper. Therefore, I received two variants of the manuscript and the reviews. I had never read reviews like these before or subsequently. It was a passionate dispute against the expressed hypothesis. Of interest is that I was not convinced either, and I felt I wanted to join the discussion and add my arguments. Finally, one of the reviewers exclaimed in exhaustion that he did not understand why the authors did not write a conventional review, which would definitely not have given rise to criticism. Indeed, a thorough consideration of already accumulated data on the subject, most of which were obtained by the very authors of the paper, would have been a useful publication. However, such an article would have lacked the spirit of VA, who loved to "stir the pot" and provoked discussion whether in the written or spoken word. Reading his papers led to an urge to out-argue him and stimulated reasoning and ideas in his opponents which otherwise would not have taken place. In all cases, the end result was the heated academic debate, a hallmark of academia.

VA knew how to pay scientific compliments. Respected female palynologists and paleobotanists still remember flattering words he uttered decades ago. The opposite is also true: a paper of mine, which was concisely but severely 
criticized by VA in the manuscript, long remained unfinished. Significant effort was needed to counter the verdict pronounced by VA and to correct and publish the paper, even though VA had forgotten his comments long ago.

VA was always surrounded by students, and they always matured into scientists who greatly differed from those it appeared he wanted them to become. He appeared an unsatisfied person, who seemed to me often troubled by the frustrations of his personal and professional life. Perhaps it was this very dissatisfaction that was transformed into hope and enthusiasm about each new person. For some time, he believed that he had finally found a true and worthy successor and went all out to transmit his knowledge, skills, and experience and to endow that person with his ideas. Alas, he felt disillusionment in time. However, this cycle always repeated with every new student. The fact that he received and measured great potential in each and every student seems to indicate that he was more of an optimist than the melancholy man?

\section{Maria Tekleva:}

I met Valentin Abramovich thanks to my university supervisor Prof. Nonna Meyer-Melikian. He had asked my supervisor to investigate the fossil pollen of gnetophytes, and she suggested this material as part of my $\mathrm{PhD}$ research. I am contributing to this volume a paper on the exine ultrastructure of several species that Valentin Abramovich and I had never got around to finishing. However, these are important species that he and his colleagues described, and the ultrastructural data will hopefully serve for their future interpretation. Gnetophytes were one of VA's favorite groups. He always returned to the subject and tried to develop a proper classification for this enigmatic group. Its members are like VA himself was: unusual and with a bold combination of features, stirring up unflagging interest in them. To interpret such a controversial group as gnetophytes, it is essential to see far and wide and prevent the ossification of ideas. There are few scientists who fulfill these criteria, and VA was one of them. His striking personality could not leave anybody indifferent. When you first met him, you felt that this was an unusual and brilliant man. It is a common saying that a gifted person is good at everything, but one keeps wondering about his wide range of interests and the depth of his knowledge. It seemed impossible to learn and do so many things in one lifetime! His stunning efficiency and tireless curiosity both made you look on him with admiring envy and inspired you as well. One of his greatest assets was how he engaged students and colleagues in research and inspired wonderment among them. He is one of those professional colleagues that enriched your career just for knowing him.

\section{Eugeny Karasev:}

Valentin Abramovich was the scientific supervisor of my postgraduate study at the Paleontological Institute. We mostly communicated by e-mail, but even such simple correspondence gave me the powerful stimulus to write my thesis.

The peculiar feature that I noticed in working with Valentin Abramovich was his global mind. His ideas were often at the forefront of science, and the facts could hardly keep up. In this regard, our paper about the new genus Permophyllocladus on leaves of the Late Permian peltasperms was a good example.

The precursors compared fronds with blister-like swellings on the rachides from the Late Permian of Western Europe with leaves of the genera Lepidopteris, Callipteris, or Alethopteris. After the work of Poort \& Kerp (1990) with the concept of "natural taxa", researchers described similar leaves and associated ovuliferous organs as Peltaspermum martinsii. Leaves similar to Peltaspermum (Lepidopteris) martinsii were found on the territory of the Russian platform in the Upper Permian deposits of the Sokovka and Vyazovka localities in 2005-2006. We described these leaves as a new taxon Permophyllocladus polymorphus and proposed a new interpretation of their morphology as phylloclades (Karasev
\& Krassilov 2007).

For almost ten years after the description of the genus, it was ignored in papers looking at plants similar to Permophyllocladus. The only exception was a work edited Taylor et al. (2009) and a review article on seed ferns (Taylor \& Taylor 2009). Finally, in 2014 a team of researchers from Western Europe came to a similar conclusion. The independence of the leaves of Peltaspermum (Lepidopteris) martinsii on the generic level was accepted, although the authors used a new name for the genus: Germanopteris (Kustatscher et al. 2014).

\section{Lyudmila Volkova:}

At tea Valentin Abramovich often told anecdotes from his personal experiences, his lab and his expedition. As any good storyteller, he knew where to embellish the story to make it more interesting and how to assert that everything happened just the way he remembered it. And then and there the main character of the story often tried to protest and to explain that it had indeed happened, but somehow in a different context. However, it was precisely VA's version of the story that thrilled the audience. There were other more serious conversations as well. VA was a widely read man and was involved in many things. So, a discussion on any subject might pop up: he could pontificate on a historical personality or a fictitious character, on theories in different areas of science, and on many other subjects, which are hard to remember but they often turned into short lectures that inspired heated debate. One of the ongoing subjects was humanism in its different aspects. For example, he would present hypothetical situations, e.g., when there are too many people for a lifeboat, or there is limited time before a hypothetical "door" closes during a chemical or nuclear attack, how do you behave in such cases, when you cannot save everybody? Or, more precisely, when you either can save some people or let all of them die? In this sense, VA stood for "absolute" humanism, i.e. to try to save everybody at any cost, even if there was no hope and this would be the end. Some other voices (save for those abstaining from the discussion) were for more rational ways around extreme situations.

What else comes to mind when I think about VA? Not only was he a terrific storyteller but he was also a great lecturer. I really enjoyed his lectures, whatever the subject: paleobotany, history, ecology, metaecology, among many others. In fact, he had a lecture on almost any subject and often without much preparation! His lectures always gathered crowds of people. VA had a remarkable memory. I often typed his papers from his dictation and was always amazed how they had already been thought out. If somebody or something distracted him - even for a long time - he always remembered where he had left off and what would come next. It seemed VA was a complex man and felt life deeply. This did not make him an outgoing personality in everyday life, but a very interesting companion.

\section{Aleksandra Sokolova (Klumova):}

Valentin Abramovich has been and still remains a person who inspires and leads in the world of Science. I became interested in paleobotany attending lectures at Moscow State University, but the love of Science was instilled in me by VA. He operated so skillfully with global knowledge, creating theories so easily and imbuing them with a deep philosophical meaning, tying them to this world so enthusiastically that no one could remain indifferent. Many of his ideas and theories seemed ambiguous - they raised the desire to argue, to learn new things, to defend your own understanding; they gave rise to a tireless stream of new thoughts and ideas in our minds. It seemed that this cycle made you a part of this new theory, and as a result you somehow began to think in terms of this theory. Perhaps this scientific magic acted in such a way only on me. However, it is working even now. When studying scientific papers by VA, I often find myself in mental conversations and discussions with him. This is probably scientific continuity, and thus Valentin Abramovich's ideas will be transmitted 
Krassilova, Zavialova, Sokolova, Maslova, Polevova, Tekleva, Volkova, Karasev, Gordenko, Bugdaeva, Markevich, Volynets, Cherepanova, Blokhina, Akhmetiev, Heth, Boucot, Nichols

from one generation to another.

I came to the Laboratory of Paleobotany at the time when VA was living and working in Haifa; our communication was intermittent and mostly conducted by electronic correspondence, so the time spent with Valentin Abramovich on scientific expeditions was especially valuable for me. Each new field season and every new trip were accompanied by the positive attitude of our leader. His unhesitating plans inspired a deep belief in success. And each end of the field season always contained a shade of disappointment: time is never enough to embrace the boundless... On the outcrops, not turning away from his work and geological hammer, Valentin Abramovich provided lectures, covering courses from paleontology, biology, petrography, lithology, and stratigraphy to history, philosophy, and metaphysics. These field lectures were more influential on me than the formal University lectures.

Valentin Abramovich was a master of the spoken word. He could dictate entire monographs without stumbling over a single word. I remember writing a report after a Mongolian expedition. I acted as stenographer, and my role was simply typing the text that Valentin Abramovich dictated from his head. I managed badly; my fingers could not keep up with the flow of VA's neat phrases. A strange feeling invaded me with each new page of continuing text: was it possible in reality? Finally, a 15-page report was written. And it seemed that we did it within an hour. Yes, Valentin Abramovich was a gifted speaker. His voice and manner of presentation had a power, forcing you to delve into the essence of the stories and empathize with the subjects, whether it was a sand lens or Sir Lancelot. It is sad that no video lectures of Valentin Abramovich are preserved. However, in some perverted way this fact allows VA to uniquely belong to the people closed to him. No one lecture or video would ever do justice to the contributions this man has made to our lives or adequately represent this intelligent and complex man. Nor would it adequately document that this man worked hard, VA was an inexhaustible toiler. He worked in the laboratory and in the field, on his way to work and on long journeys. I remember once, during a trip to Mongolia (summer 2008), Mitya Vasilenko and I were watching the Summer Olympic Games on TV and were vehemently rooting for our athletes. Valentin Abramovich was angry about it. He wondered: why do you both waste your time worrying about unfamiliar people? Sitting in front of the TV will not make you any stronger or faster or tougher. If you want to achieve the best results in sports, train and win! If you want to increase the ranking of your country on the world stage, perform your duties and do your best! That, I think, was precisely his point. He worked with full dedication and achieved incredible heights. He taught us to delve thoroughly into the essence of the research and never limit ourselves to a one-sided view of the subject of study. He never related to us, his students, in a one-sided way; it was important for him to know about each of our lives; he took a lively interest in the lives of our families, our hobbies, and extra-scientific talents. Such informal relation of Genius lends self-confidence and also a special gratitude to him. I count my blessings for having met Valentin Abramovich. Now we just have to make good on the down payment, trying to turn into reality the ideas he left for us.

\section{Acknowledgements}

We are thankful to Mr. Kerry Franchuk (Carleton University, Ottawa, Canada) and Prof. Michael Zavada (University of Texas, United States) for linguistic corrections of the text and to Prof. Alexei Herman (Geological Institute, Russian Academy of Sciences, Moscow) for providing a photo of VA at Moscow Geological Congress.

\section{Literature cited}

Karasev, E.V. \& V.A. Krassilov 2007. Late Permian phylloclades of the new genus Permophyllocladus and problems of the evolutionary morphology of peltasperms. Paleontological Journal41(2): 198-206.
Kustatscher, E. et al. 2014. Sphenophytes, pteridosperms, and possible cycads from the Wuchiapingian (Lopingian, Permian) of Bletterbach (Dolomites, Northern Italy). Review of Palaeobotany and Palynology 208: 65-82.

Poort, R.J. \& H. Kerp 1990. Aspects of Permian palaeobotany and palynology. XI. On the recognition of true peltasperms in the Upper Permian of Western and Central Europe and a reclassification of species formerly included in Peltaspermum Harris Rev. Review of Palaeobotany and Palynology 63(3-4): 197-225.

Taylor, E.L. \& T.N. Taylor 2009. Seed ferns from the late Paleozoic and Mesozoic. American Journal of Botany 96(1): 237-251.

Taylor, T.N., E.L. Taylor \& M. Krings 2009. Paleobotany: The biology and evolution of fossil plants. Amsterdam, Boston: Academic Press, 2009. $1230 \mathrm{pp}$

\section{From Paleobotanists of Vladivostok}

Eugenia Bugdaeva, Valentina Markevich, Elena Volynets, Marina Cherepanova, Nadezhda Blokhina

Institute of Biology and Soil Science FEB RAS,

Vladivostok 690022 Russia

\section{Бугдаева Е.В., Маркевич В.С., Волынец Е.В., Черепанова М.В., БАохина Н.И. \\ От палеоботаников ВАадивостока}

Valentin Abramovich Krassilov - a talented paleobotanist, a scientist of world renown, and an intelligent and wonderful person is no longer with us. An appreciation of his extraordinary life is hard to write, particularly as we knew him well and he was a dear friend.

Krassilov became widely known in the scientific community of the 1960s, when he literally burst into the world of paleobotany. His first publications demonstrated immediately that here was an outstanding researcher. VA amazed those around him with his tireless energy, his incredible capacity for work, his ability to describe and explain complex topics with great clarity, and his originality of thinking. He introduced numerous fresh approaches to tackling many problems within the natural sciences. At the age of 27 , he defended his PhD thesis on the Early Cretaceous Flora of the Southern Primorye, and two years later his monograph on this topic was published, the content of which has relevance to the present day. He demonstrated an admirable ability for studying in quantity paleobotanical and geological material, as well as a deep knowledge of stratigraphy and paleobotany; something quite revolutionary for that time. For the first time in this subject area VA employed cuticular-epidermal analysis that allowed him to reveal new structural features within the leaves and reproductive organs of fossil plants.

Eight years later, VA defended his higher doctoral thesis entitled "Paleoecology of terrestrial plants and paleoecological method in stratigraphy of continental strata". At 35, he became one of the youngest in paleontology and stratigraphy to achieve such a doctorate.

Each monograph that VA published introduced novel scientific concepts. The most significant works - "Evolution and biostratigraphy" (1977), "Cretaceous period. The evolution of the earth's crust and the biosphere" (1985), "The origin and early evolution of flowering plants" (1989), "System Theory of Evolution" (2014) became reference books not only for paleobotanists but for many scientists across a broad range of disciplines. They increased the number of followers and apologists of his ideas.

For many years, VA worked in Vladivostok, first in the Far East Geological Institute, and then in the Institute of Biology and Soil Science of the Far Eastern Scientific Center. In 1971 he organized the Laboratory of Paleobotany - the only one of its kind in the Asian part of USSR. He continued to lead this laboratory until 1990. 


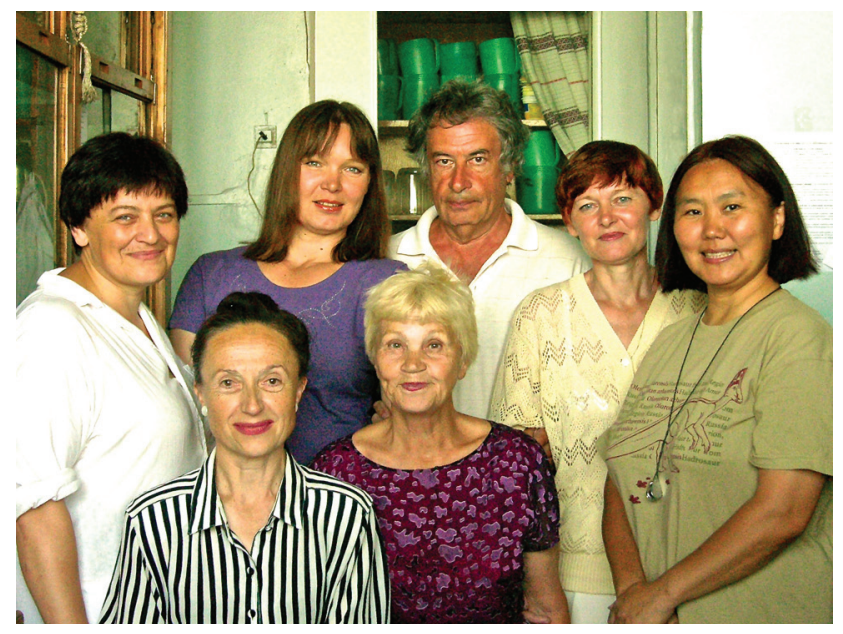

Valentin Abramovich and his colleagues from Laboratory of Paleobotany, Institute of Biology and Soil Science FEBRAS, Vladivostok, 2005. Left to right: Elena Volynets, Nadezhda Blokhina, Marina Cherepanova, Valentina Markevich, Valentin Krassilov, Claudia Novikova, Eugenia Bugdaeva

Krassilov became actively involved in the training of young researchers, passing on his vast experience and knowledge, and showing goodwill and readiness to provide any help that was requested. V.A. could point out new horizons, inspire and captivate those around him with his interesting ideas. He always created favorable conditions for scientific work, and freely exchanged ideas, helped with practical processing of materials, assisted in obtaining results, and so stirred the enthusiasm of those in his lab that they were ready to work tirelessly day and night. VA supervised numerous doctoral research projects and the result of his efforts was the creation of a world-class paleobotanical school in the Russian Far East. In 1983 he became a professor.

VA did not belong to the group of so-called "armchair scientists". He was a good field worker, working on expeditions, as they say, "from dawn to dusk", steadfastly enduring personal discomfort, bad weather, and overcoming logistic difficulties. His persistence and enthusiasm usually rewarded him with unique finds of plant fossils. The huge number of samples collected by VA currently forms the basis of the paleobotanical collection of the Institute of Biology and Soil Science FEB RAS.

The results of research conducted by VA are reflected in his numerous papers and monographs published not only in our country but also abroad. Yet the personality of Krassilov the scientist is determined not only by his professional achievements, but perhaps more importantly by his spiritual qualities.

Those of us privileged to have worked with him in Vladivostok were always aware of his sincere attention and constant friendly support, even after his departure, first to Moscow and then to Israel, despite there being many thousands of kilometers between us. We could always ask for advice or consultation on various problems. VA was distinguished by brilliant erudition and open-mindedness. Conversations with him about problems in paleobotany, tectonics, stratigraphy, geology, or the evolution of the biota could gradually move to a discussion of ancient Greek mythology, philosophy, literature, theater and film premieres of new products, or biographies of prominent people. Outwardly VA appeared serious and unsmiling but this was misleading. Within his close circle he was a completely different person: he was the life and soul of the group and he told funny stories. And how creatively he congratulated his colleagues! He might cover a wall with newspapers, draw friendly caricatures, or write humorous poems, always given with warmth, sincerity and with the intention of raising the morale of the laboratory of Paleobotany.

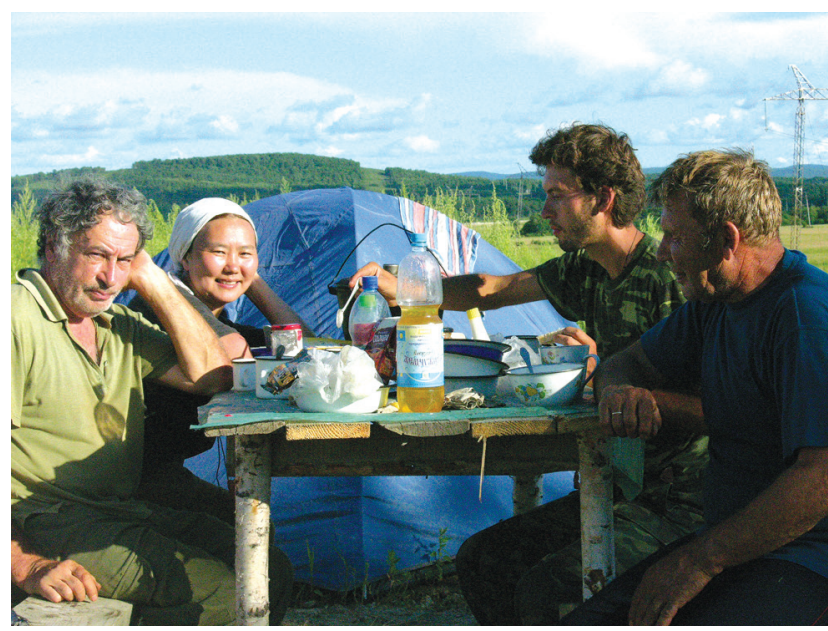

Valentin Abramovich with his colleagues Eugenia Bugdaeva, Dmitry Vassilenko on the field work in the Amur River region, 2005

Fate interfered and shortened his lifetime prematurely, breaking great plans. However his life left a bright trail throughout science and our own lives. The wonderful memory of Valentin Abramovich Krassilov, our Teacher, will always remain with us.

\section{Acknowledgements}

The authors expresses their deep appreciation to Teresa and Robert Spicer (Open University, Milton Keynes) for checking up on the English and to Dr. Tatiana Kodrul (Geological Institute, Russian Academy of Sciences, Moscow) and Mr. Li (Jilin University, Changchun) for providing photos of VA.

\section{Он посвятил свою жизнь науке}

Михаил Алексеевич Ахметьев

Геологический институт Российской академии наук, Москва

\section{Akhmetiev, M.A. He devoted his life to science}

С прискорбием узнал о смерти Валентина Абрамовича. С ним ушла целая эпоха отечественной палеоботаники, блестящим представителем которой он был, наряду с Аругим выдающимся ученым - С.В. Мейеном, с которым их многое объединяло. Они были не похожими внешне, обладали разными характерами и темпераментами. Покойный Сергей Викторович нередко Аружески называ^ его импрессионистом, подчеркивая тем самым не только безграничную увлеченность Вацентина Абрамовича, его внимание к новым веяниям в науке, но и быстрыми реакциями на них. Им обоим отечественная палеоботаника обязана достижениями современного уровня. В научном наследии В.А. Красилова несколько Аесятков монографий и сотни статей, охватывающих широкий спектр научных направ ений.

Известно, что внимание ученых-естественников во второй половине прошлого столетия было привлечено к Авум важнейшим парадигмам, оказавшим влияние на все научные Аисциплины, связанные с жизнью нашей планеты. Оставались неразрешенными также извечные загадки ботаников: пути эволюции растительного мира и происхождение покрытосеменных.

Первая из парадигм - принципиально новая трактовка образования тектонических структур Земли. Она связана с признанием формирования их горизонтальными Авижениями и перемещением материковых бло- 
Krassilova, Zavialova, Sokolova, Maslova, Polevova, Tekleva, Volkova, Karasev, Gordenko, Bugdaeva, Markevich, Volynets, Cherepanova, Blokhina, Akhmetiev, Heth, Boucot, Nichols

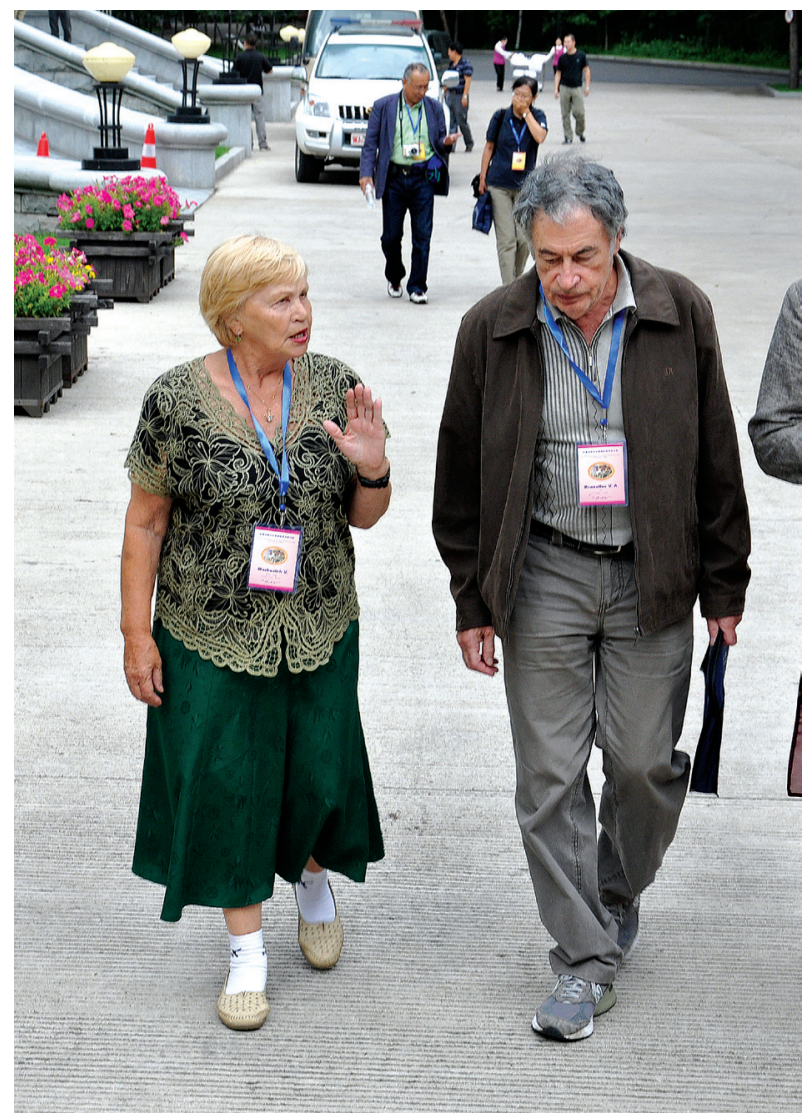

Valentina Markevich and V.A. Krassilov discuss the paleobotanical problems. Yichun, China (2011)

ков. Новая концепция, за которой закрепилось название «мобилизм», появилась в результате постановки большого объема геофизических исследований в Мировом океане, сопровождавшихся открытием спреАинговых зон в осевых частях срединноокеанических хребтов. Аанные, полученные при реализации проекта глубоководного бурения, не могАи оставить равноАушными специалистов, трудившихся в разных областях естествознания.

Вторая парадигма касалась расшифровки природы биосферных кризисов на переломных этапах развития нашей планеты. Речь илет о признании ведущей роли импактных событий метеоритной природы, периодически наносящих большой урон биоте Земли в перемомные периоды ее развития.

Известно, что парадигму мобилизма С.В. Мейен воспринял положительно. Аیя него Аоказательством ее было пространственное сб์лижение верхепалеозойских толщ с гонАванской и еврамерийской флорами в Центральной Азии при их значительном расхождении в аругих регионах Земного Шара. В.А. Красилов, не отрицая проявлений в прошлом горизонтальных сАвигов большой амплитуды, тем не менее, опираясь на собственные фитогеографические построения, не стал столь категоричным сторонником мобилистской парадигмы. Впрочем, ортодоксальные тектонические построения «фиксистов» он также не разделял. Ему ближе были представ ения, развиваемые сторонниками «расширяющейся Земли». Они прозвучали в его научном сообщении в Москве в середине 70-х годов на объединенном заседании Тектонического и стратиграфического отАелов ГИН РАН, а также в публикациях «Тектоника плит и ротационный режим планеты» (Krassilov 1976a) и «Палеонтология и мобилизм» (Krassilov 1974). Эта проблема, хотя и косвенно, также затрагивацась им в статье «Тектогенез и эволюция климата Тихоокеанского

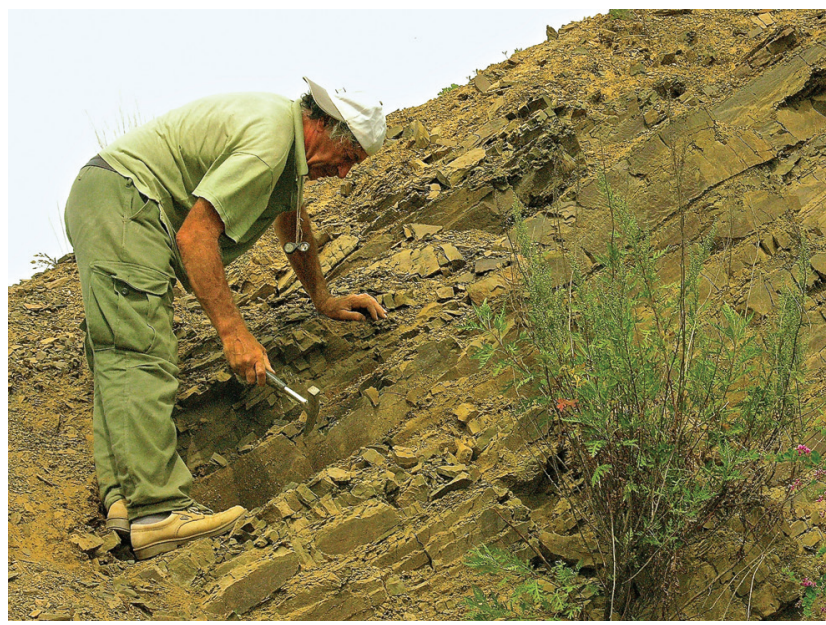

Valentin Abramovich on the locality of the Albian angiosperms near Bolshoi Kamen town, Primorskii Region, Russia (2005)

пояса в меловом периоде» (Krassilov 1976b).

Неоднозначным было отношение Валентина Абрамовича и к импактной парадигме Альваришей с соавторами (Alvarez et al. 1980) и Сю (Hsü 1980), трактующих с новых позиций природу биосферных событий на рубеже мела и палеогена. Падением метеорита, как им казалось, Аегче объяснить причины вымирания беннеттитов, хейролепидиевых, кейтониевых, иноцерамов, белемнитов, аммонитов, рудистов и Аинозавров. Известно, что эта парадигма быстро нашма своих сторонников и Ао сих пор принимается, особенно армией журналистов, в качестве единственной причины всех глобальных катастрофических событий в пограничном интервале. Валентина Абрамовича всегда привлекали мюбые новаторские илеи. Импактная парадигма не была исключением. С падением метеорита и последующим похолоданием он поначалу был склонен связывать редукцию папоротников в разрезах пограничных слоев мела и палеогена Сахалина. Позже, не отрицая значения импактных событий Аля глобального трассирования границы мела и палеогена, В.А. Красилов вернулся к их трактовке на рубеже мела и палеогена с позиций граАуализма. Он опирался на свои собственные Аанные по смене флор в хорошо знакомых ему регионах Аальнего Востока России: на Сахалине, в ЗейскоБуреинском осадочном бассейне, во впадинах Южного Приморья, в Сихотэ-Алинском вулканическом поясе.

В ряду извечных палеоботанических загадок была и остается проблема происхождении покрытосеменных. Этой проб̆леме, как никто Аругой, он уделял внимание практически на всех этапах своей научной деятельности, начиная со статьи, поАготовленной на рубеже 60-х и 70-х годов «Предки покрытосеменных» (Krassilov 1976c). За ней последовали пуб̆ликации: «Семейство проангиоспермовых и проблемы предков покрытосеменных» (Krassilov 1975), «Происхождение покрытосеменных» (Krassilov 1977), «Проангиоспермы и происхождение цветковых растений» (Krassilov et al. 1997) и Ар. Весь цикл работ по этой теме завершился известной монографией, опубликованной в Болгарии. Ее название в русском переводе «Происхождение покрытосеменных, морфологические и экологические аспекты» (Krassilov 1997).

Вопросы систематики и морфологии Аревнейших покрытосеменных, экологии, их климатических преАпочтениях рассматривались им во многих статьях. Не обошел он и их возможных предшественников - гнетовых. Сведения о последних приведены в совместной публикации с Е.В. Бугдаевой «Комплекс гнетофитов из раннего мела Заб̆айкалья (Krassilov \& Bugdaeva 2000) и с M.A. Ахметьевым (Akhmetiev \& Krassilov 
2002) в статье об их плодоношениях из нижнемеловых отможений впадины Бэйпяо Северо-Восточного Китая. В этой впадине гнетовые были обнаружены в одной из пачек осадочной толщи вместе с остатками скелетов оперенных Аинозавров и Аревнейших птиц, а также насекомых и Аругих представителей наземной биоты. Кстати, из отможений впадины Бэйпяо происходят и находки Аревнейших покрытосеменных (Archaefructus и Ар.), впервые описанные Сунь Ге и А. Аильчером с соавторами в конце прошедшего столетия.

В.А. Красилов внес большой вклаА в методику изучения растительных мега- и микрофоссилий. Трудно назвать иначе как ювелирным способ извлечения им пыльцы из желудков насекомых мезозоя, что имело большое значение Аля Аоказательства присутствия в мезозое энтомофилов и их паралмельной эволюции с насекомыми.

Он в совершенстве освоиц, Аополнил и широко применял кутикулярный анализ при изучении голосеменных растений и Аревнейших покрытосеменных.

Известно, что углеводородное сырье имеет, в основном, растительное происхождение. Проблемы нефтегазоносности и угленакопления также не прошАи мимо его внимания. Это нашло отражения в пубмикациях «Меловое нефтенакопление» (Krassilov 1983) и «У гленосные отложения советского Аальнего Востока» (Krassilov 1992a). В.А. Красиловым был написан заключительный раздел «Нефтегазоносность» в колмективной сводке А.П. НайАина и Ар. «Меловой периол. Палеогеография и палеоокеанология» (Naidin et al. 1986) с выделением четырех этапов наиболее значительного накопления углеводородов в меловой период: титон-берриасский, баррем-аптский, альбский и туронский. ОАновременно им подмечена корреАяция этих этапов с колебаниями уровня моря и кАиматическими оптимумами.

Кроме крупных сводок по региональным меловым флорам Аальневосточного региона, опубликованным в течение первых десятилетий, Валентин Абрамович всегда поражал неординарном широким подходом к решению многих проблем. В первую очередь это касалось палеофлористики, стратиграфии, а также памеокмиматологии, вопросам развития биосферы. Особенно его интересова^а природа экологических и климатических кризисов на пограничных рубежах главных подразделений геохронологической шкалы, а также проблемы тектогенеза. Причинами вымирания Аинозавров в конце мелового периода, по его мнению, была смена пищевых ресурсов, похолодание и радиация конкурентов - млекопитающих.

После краткого обзора основных направлений научной Аеятельности Валентина Абрамовича целесообразно более полробно осветить более ранний периоА, непосредственно связанный с изучением Аальневосточного региона, тем более, что очевидцев его первых успехов с каждым годом становится все меньше. Этот период продолжался более четверти века, хотя к старым местам он неоднократно возвращался и после своего переезда из ВАадивостока в Москву, оставаясь куратором созАанной им маборатории палеоботаники в краевом Биолого-почвенном институте, гАе и сейчас успешно трудятся его ученики.

С В.А. Красиловым я впервые встретился во ВАаАивостоке весной 1965 года на 2-м Межведомственном стратиграфическом совещании по южной материковой части Аальнего Востока (Хабаровский, Приморский края и Амурская область). На совещании он оАновременно принимал участие в работе двух секций: Меловой и Палеоген-Неогеновой. На первой Валентин Абрамович представ яя материал по стратиграфии и флорам нижнемеловых впадин Приморья. На второй секции, на заседаниях которой в процессе обсуждения материалов мы и познакомились, он палеоботаническими методами обосновывал возраст отдельных подразделений цагаянской серии Зейско-Буреинского осадочного бассейна. В те годы завершались геологосъемочные и редакционно-издательские работы региональной серии Аистов Геологической карты СССР м-ба 1:200000, поэтому все, что он сообщал, геологи слушали с вниманием. Его предложения были настолько аргументированы, что все заинтересованные Аица согласились с его АОводами, хотя они заметно отАичались от заключений Т.Н. Байковской - ученицы А.Н. Криштофовича, продолжавшей после его кончины изучение цагаянской фморы. Основные разногласия В.А. Красилова и Т.Н. Байковской были в понимании объемов виАов Аоминирующих таксонов этой флоры. В последних публикациях по цагаянской флоре, уже после смерти А.Н. Криштофовича, Т.Н. Байковская (Baikovskaya 1959, Kryshtofovich \& Baikovskaya 1966) описала широкий спектр вилов Platanus и формального рода Trochodendroides. Валентин Абрамович свел более трех десятков выделенных ею видов только к двум: Trochodendroides arctica (Heer) Berry и Platanus raynoldsii Newb., рассматривая разАичия в строении Аистового края этих и Аругих таксонов, как морфологические вариететы кажАого из Авух виАов. К ним же он присовокупил и ряд таксонов Т.Н. Байковской, принаАлежавших, по ее мнению, Аругим родам. В результате в итоговой публикации «Цагаянская флора Амурской области» (Krassilov 1976d), разнообразие цагаянских растений сократилось на Аобрый Аесяток видов, хотя Валентином Абрамовичем были описаны из этой же фморы не менее Авух Аесятков новых, в том числе принадлежавших к родам ранее неизвестным в цагаянской флоре. Научные расхожАения, к сожалению, отразились на Аальнейшей судьбе самого Валентина Абрамовича. Он рассчитывал перейти на работу в БИН АН СССР и перебраться

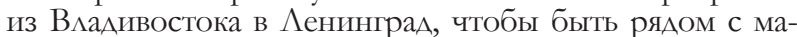
терью, которая работала во второй столице России преподавателем английского языка. Это ему не удалось.

Во ВАадивосток В.А. Красилов попал по распределению в конце 50-х годов после окончания Харьковского университета, где одним из его наставников был проф. В.П. Макридин. Сразу начал работать в Геологическом институте в маборатории М.Н. Грамма, выезжая в первые годы на полевые работы в нижнемеловые угольные бассейны Южного Приморья. Изучая разрезы, он собрал богатейшие комлекции нижнемеловых, преимущественно альббских растений. Ранее в альбоских комплексах А.Н. Криштофович впервые обнаружил и описал Аревнейшие находки покрытосеменных растений на Аальнем Востоке. Валентин Абрамович не только повториц, но и расширил их представительство. Результатом изучения нижнемеловой фморы явились опубликованная монография и успешно защищенная кандидатская Аиссертация. Как ведущий палеоботаник маборатории В.А. Красилов с этого момента стал фактическим руководителем всех проводимых в ее стенах палеоботанических работ. Продолжением его Аичных исследований стали работы на Сахалине. Предметом основного внимания оставались те же проб̆лемы: систематика, экология, флорогенез и эволюция меловых флор, проблемы фитогеографии, изучение флор пограничных слоев мела и палеогена с детальной характеристикой ранее плохо изученных Аатских флор бошняковской свиты. Им впервые были обнаружены остатки нильссоний и описаны новые роды и виды покрытосеменных. Особенно тщательно Валентином Абрамовичем были изучены разрезы меловых отложений Западного Сахалина от северной части Александровского района до перешейка Поясок. (Камышовый хребет, река Най-Най с участком побережья у ее устья, р. Августовка и Бошняковский перевац, участок побережья межАу мысом Хойнджо и Каменной падью). Научный итог проведенных исследований обобщен в монографии «Меловая флора Сахалина» (Krassilov 1979). 
Krassilova, Zavialova, Sokolova, Maslova, Polevova, Tekleva, Volkova, Karasev, Gordenko, Bugdaeva, Markevich, Volynets, Cherepanova, Blokhina, Akhmetiev, Heth, Boucot, Nichols

На исследования молодого ученого обратили внимание руководители АаАьневосточного отделения РАН академики А.П. Капица и Н.Н. Воронцов, создав ему условия Аля Аальнейшего научного роста. Валентин Абрамович перешел работать во вновь образованный Биолого-почвенный институт этого ОтАеления, возглавив, как было уже отмечено, созданную им Палеоботаническую мабоораторию. Уже работая в Москве, академики не забывали своего талантАивого комлегу, поспособствовав его переезду в Москву в 90-х годах.

В столице, поначалу он не имел возможности работать в Геологическом или Палеонтологическом институтах АН СССР. На рубеже столетий в этих организациях не было вакансий и происходили массовые сокращения ученых. В Палеонтологический инс-

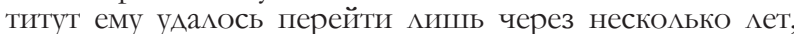
создав в нем мабораторию палеоботаники, успешно функционирующую по сей день, поэтому В.А. Красицову было преАложено возглавить вновь созАанный институт по охране природы. В задачи нового института, размешавшегося в ближайшем Подмосковье в имении Трубецких, входило изучение проблем экологии и защиты окружающей среды. Это новое Аля него направмение научной деятельности отражено в одной из статей в популярном журнале «Природа» - «Охрана природы, принципы, проб̆лемы, приоритеты» (Krassilov 1992b). С информацией о задачах по охране природы в России он выступал на Международном конгрессе в Бразилии. Валентин Абрамович организовал проведение конференции, тематика которой не в полной мере отвечала профилю института, а была больше направлена на реконструкцию экологических и климатических обстановок обитания ископаемых растений, их тафономию.

С Валентином Абрамовичем при парацлельных по времени работах на Аальнем Востоке мы встречались, хотя и не часто, причем не только в полевой, но и в АОмашней обстановках. Результатом совместных работ на разрезах Тавричанского месторождения к северу от В $\Lambda$ Аивостока явилась статья, подготовленная совместно с палинологами Г.М. Братцевой и М.А. Болотниковой о стратиграфии и флоре разреза п-ва Речного с подробной палеоботанической характеристикой угловской, надеждинской и усть-давыдовской свит. Материалы, полученные на побережье залива, были дополнены Аанными по разведочным скважинам, пробуренным в пределах самого месторождения. Работая вместе на разрезах полуострова, я впервые обратил внимание на то, как он тщательно расчищает разрезы, поочередно оруАуя киркой и мопатой, собирает ископаемые остатки, их документирует и Аает полевую оценку представительности собранного материала.

В 1970 году перед уходом на «Витязе» в Тихий океан, я около двух недель провел во ВАадивостоке. Вместе с Валентином Абрамовичем и его колмегами ходили в театр на «модный» в то время спектакль «Трамвай желаний», а также участвова^и в Ноябрьском праздничном шествии по набережной ВАаАивостока и его центральным улицам. Вечером мы поднялись на вершину одного из холмов и АюбоваАись праздничной панорамой города. В Аомашней семейной обстановке мы отметими праздник. Вскоре после моего возвращения из рейса «Витязя», Валентин Абрамович побывац у меня Аома в Москве, где мы просмотрели многочисленные слайды с растениями тропиков. Приходиц он и в нашу цаб̆ораторию в Геологический институт АН СССР. Его заинтересовала привезенная мною гербарная колмекция хвойных растений из Новой Каледонии и Новой ЗеланАии. Я поделился с ним собранным материалом. Кутикулярные препараты из экземпляров этих сбооров, насколько мне известно, он использовац в качестве сравнительного материала при изучении ископаемых хвойных.

А^я меня были важны его замечания и сужАения о колмекции Аатской флоры из Нижнего Приамурья, ко- торую мы с В.А. Вахрамеевым собрали в окрестностях поселка Мало-Михайловка в середине 70-х годов. Вместе с В.А. Красиловым пришли к заключению о близости АОминирующих компонентов этой фморы (Metasequoia, Corylus, Trochodendroides arctica) с Аатской верхнецагаянской фморой Амурской области и бошняковской фцорой Сахалина. Его впечатления о результатах совместного просмотра мало-михайловской флоры можно найти в изАанной им монографии по цагаянской флоре (Krassilov 1976d:32).

К сожалению, в последние десятилетия мы с Вацентином Абрамовичем стали встречаться реже. Ранее объединявшая нас Аальневосточная тематика отошла на второй план, уступив место Аругим проблемам. В послеАний раз несколько мет назаА после палеоботанической конференции в Ичуне (Северо-Восточный Китай), мы вели с ним обстоятельный разговор, поздно вечером, не спеша, прогуливаясь по амурскому галечнику в Цзяине.

В моей памяти Валентин Абрамович навсегда останется как пример ученого, беспредельно преданного науке, новатором в развитии ее новых направлений, причем не только в палеоботанике, но и в Аругих обАастях естествознания.

\section{Literature cited}

Akhmetiev, M.A. \& V.A. Krassilov 2002. New find of proangiosperms and correlation of the late Mesozoic lacustrine deposits of eastern Asia. Geology, Stratigraphic Correlation 10:105-109.

Alvarez, L.W., W. Alvarez, F. Asaro \& H.V. Michel 1980. Extraterrestrial cause for the Cretaceous-Tertiary extinction. Science 208 (4448):1095-1108.

Baikovskaya, T.N. 1959. Materials on Tsagayan flora of Zeya-Bureya Plain. In: Problems of Botany. Vol. 4, pp. 253-274, Izdatel'stvo AN SSSR, Moscow (in Russian). [Байковская T.H. 1959. Материалы по цагаянской фморе Зее-Буреинской равнины // Проблемы ботаники. Т. 4. Москва: ИзА-во АН CCCP. C. 253-274].

Hsü, K.J. 1980. Terrestrial catastrophe caused by cometary impact at the end of Cretaceous. Nature 285:201-203.

Krassilov, V.A. 1974. Paleontology and mobilism. Geotektonika 1: 18-28 (in Russian). [Красилов В. А. Палеонтология и мобимизм // Геотектоника, 1974. № 1. С. 18-28].

Krassilov, V.A. 1975. Dirhopalostachyaceae - a new family of proangiosperms and its bearing on the problem of angiosperm ancestry. Palaeontographica Abt. B 153:100-110.

Krassilov, V.A. 1976a. Plate tectonics and rotation regime of a planet. Iqvestiya AN SSSR 1:74-82 (in Russian). [Красилов B.A. 1976. Тектоника плит и ротационный режим планеты // Известия АН СССР, сер. геол. № 1. С. 74-82].

Krassilov, V.A. 1976b. Tectogenesis and climate evolution in the Pacific belt in the Cretaceous. Doklady sovetskib geologov k mezhdunarodnoi geologicheskoi konferentsii (in Russian). [Красилов В.А. 1976. Тектогенез и эволюция климата Тихоокеанского пояса в меловом периоде // Аокл. советских геологов к межАунар. геол. конф.

Krassilov, V.A. 1976c. Ancestors of angiosperms. Priroda 1: 34-42 (in Rissian). Красилов В.А. 1976. Предки покрытосеменных // Природа. № 1. С. 34-42].

Krassilov, V.A. 1976d. Tsagayan flora of Amur Region. Nauka, Moscow, 92 pp. (in Russian). [Красимов В.А. Цагаянская флора Амурской области. М.: Наука, 1976.92 с.].

Krassilov, V.A. 1979. Cretaceous flora of Sakhalin. Nauka, Moscow, 182 pp. (in Russian). [Красилов В.А. Меловая фмора Сахалина. М.: Наука, 1979. 182 с.].

Krassilov, V.A. 1997. Angiosperm Origins: Morphological and Ecological Aspects. Pensoft, Sofia, 270 pp.

Krassilov, V.A., E.V. Bugdaeva, V.S. Markevich \& N.P. Maslova 1997. Proangiosperms and origin of angiosperms. In: Russian Science. International science foundation, Russian Foundation for Basic Research, Moscow (in Russian). [Красилов В.А., БугАаева E.B., Маркевич В.С., Маслова Н.П. 1997. Проангиоспермы и происхождение цветковых растений // Российская наука: Выстоять и возродиться. МежАународный научный фонд. Российский фонд фундаментальных исследований. М.: Наука]. 
Krassilov, V.A. \& E.V. Bugdaevea 2000. Gnetophyte assemblage from the Early Cretaceous of Transbaikalia. Palaeontographica Abt. B 253(4-6):139-151.

Krassilov, V.A. 1983. Cretaceous oil and gas accumulation. Tik.hookeanskaya Geologia 5: 80-89 (in Russian). [Красилов B.А. 1983. Меловое нефтегазонакопление / / Тихоокеанская геология. № 5, 80-89].

Krassilov, V.A. 1992a. Coal-bearing deposits of the Soviet Far East. Geological Society of America Spec. Paper 267:263-268.

Krassilov, V.A. 1992. Nature Conservation: Principles, Problems, Priorities. Inst. Nat. Cons., Moscow, 174 pp. (in Russian). [Красилов B.A. Охрана природы: принципы, проблемы, приоритеты. М.: Ин-т охраны природы и заповеА. Аела, 1992. 174 с.].

Kryshtofovich, A.N. \& T.N. Baikovskaya 1966. Upper Cretaceous Tsagayan flora in Amur Region. In: Kryshtofovich, A.N.: Selected papers. Vol. 3. Izdatel'stvo AN SSSR, Moskva, Leningrad (in Russian). [Криштофович А.Н., Байковская Т.Н. 1966. Верхнемеловая флора Цагаяна в Амурской области // Криштофович А.Н. Избранные труды. Т.3. Москва, АенинграА, ИзА-во АН СССР. С. 184-320].

Naidin, D.P., A.P. Pokhialainen, Y.I. Kats \& V.A. Krassilov 1986. Cretaceous. Paleogeography and Paleooceanology. Nauka, Moskva (in Russian). [НайАин А.П., Похиалайнен А.П., Кац Ю.И., Красилов В.А. 1986. Меловой периол. Палеогеография и палеоокеанология. Москва: Наука].

\section{In memory of Prof. Valentin Krassilov}

Giora Heth

Institute of Evolution, University of Haifa, Mount Carmel, Haifa 3498838, Israel

\section{Хет Г. В память о профессоре Валентине Красимове}

Prof. Valentin Krassilov joined the Institute of Evolution at the University of Haifa 15 years ago as an already world renowned paleobotanist. In the years when I knew him since then, I saw his ability to overcome scientific challenges despite lacking the proper infrastructure for his research and the necessity of speaking a more one foreign language. The fruits of his scientific creativity, several books, including Late Cretaceous (Turonian) Flora of Southern Negev, Israel and Plant-Arthropod Interactions in the Early Angiosperm History, and articles that he wrote in this short time, testify to the quality and quantity of his contribution to paleobotanical research in Israel. Prof. Krassilov had a quiet, gentle nature, but, even in short sporadic meetings and guest lectures that he gave to my students and the variety of lectures that he gave through the years in the Institute; he conveyed clearly the intensity of his intellectual strength. During his time in the Institute, he expressed his original thinking in challenging, revolutionary and brave opinions and an impressive depth of thought and breadth of interdisciplinary knowledge. Beyond his specific professional scientific niche, it was exciting to be exposed to his vast knowledge about evolution and the history and philosophy of science. His sudden untimely death brought deep sorrow and shock to all his colleagues in the Institute and abroad. A few days before his death, I spoke with him briefly about his recent papers about evolution, life, and humanity and we decided to continue our discussion in the near future, talks that unfortunately will never be able to happen. Prof. Krassilov will be sorely missed but fondly remembered.

\section{Some Thoughts about Human Behavior}

Arthur J. Boucot \& Kathryn M. Nichols

Department of Integrative Biology, Oregon State University, Corvallis, Oregon 97331, U.S.A.

1235 Estes Street, Lakewood, Colorado 80215, U.S.A.

\section{Буко А.Аж., Николс К.М. Некоторые мысли о поведении чемовека}

Our departed friend and colleague Valentine "Val" Krassilov was a paleontologist and evolutionist who as a skilled paleobotanist and taxonomist had described important Mesozoic floras from the Far East, the pollen content of Permian insect guts from the Urals and Cretaceous trace fossils from Israel to name a few of his contributions. He was concerned, however, not just with the careful taxonomic-descriptive but also with the "why" of the biotas. In his hands the "why" especially concerned the evolutionary relations of organisms and how these expressed themselves.

Following in Val's footsteps we offer observations about some evolutionary characteristics of human behavior from the first appearance of the genus Homo about 2 million years ago to the present. These observations are based on our recent study of anthropological and archaeological literature. The conclusion offered herein is that "basic" human behaviors have been unchanging during these 2 million years. However, technologies developed by Homo have become more and more exponentially more complex through time culminating in the present "explosion" of technological changes. The following material has been "abstracted" from our on-going study (in prep.).

Critical to an understanding of Homo's evolutionary origins is George Gaylord Simpson's concept of "Quantum Evolution." Simpson demonstrated, as a taxonomist morphologist that despite Darwin's suggestion that all taxa, high and low, should be connected to each other by a chain of species there is no evidence for these "intermediate" species between families and higher taxa. How can one account for this absence of "in- 
termediate" species? Simpson suggested that high level endemism, very small populations, combined with very rapid evolution would result in absence from the fossil record as well as from the present. Using these parameters the genus Homo can now be addressed. Currently, Homo these days is assigned to the family Hominidae. This is merely a taxonomic convention. In addition, Homo and its species constitute the subfamily Homininae. But there is a significant morphological, behavioral, and physiological gap between the species of Homo and their putative ancestors hominid ancestors such as Australopithecus. Therefore, we propose that this profound gap is the result of quantum evolution! Thus far, there is no evidence for a smooth, species-to-species transition from the other members of the Hominidae to the species of Homo fossil and extant is lacking.

The first evidence of Homo dates from about 2 million years ago. This evidence is the simply chipped flints of the Oldowan, possibly made by Homo erectus. These artifacts are superceded by the sophisticated stone axes of Homo erectus in the Acheulian. More complex lithic industries developed by developed by $H$. neanderthalensis and $H$. sapiens then followed in time. Ever ever more complex tools and ultimately structures were then developed up to the present.

A brief summary of some of the many distinctive skeletal differences between Hominidae and the other members of the Hominidae that demonstrate a major morphological set of differences that materially affect behavior includes the following:

1. Relatively short fingers and a long thumb, shoulder differences, brain size, longer legs relative to arms, bipedal, no prehensile toe capability, parallel-sided rib cage as contrasted with funnel-shaped rib cage, distinctive pelvic morphology (much smaller), foramen magnum location, post-canine tooth morphology, small mouth, sexual dimorphism, absence of a baculum and a small mouth.

2. The female human pelvis is modified for bipedalism resulting in a birth attitude involving a $90^{\circ}$ rotation with a "backward presentation" that requires "helpers".

3. The small mouth combined with relatively small post-canine teeth and relatively weak jaw musculature combined with a relatively small pelvis all indicate an omnivorous, relatively soft diet unlike that of the dominantly herbivorous other Hominidae living and fossil. They also have a relatively long small intestine and short colon in contrast to the reverse situation in the other Hominida.

4. Additionally, Homo is relatively hairless except on the top of the head, (5) lacks estrus in the female, and (6) is characterized by handedness.
A very significant physiological characteristic is the need for a relatively large protein diet in the human infant about 6 months after birth when the female's milk is no longer adequate for this need. Therefore, the use of soft, protein-rich food that can be provided by cooking both meat and proteinrich legumes becomes necessary. Infants are then fed this "baby food" either by adult to infant mouth-to-mouth transfer after softening it by chewing and adding saliva or by use of some type of utensil. This crucial difference makes the use of fire from the very appearance of Homo a necessity!

Turning now to a few of the many, many items that distinguish hominins from the other hominids we can list the following:

1. There is abundant evidence from the Oldowan on for meat eating by humans, but plant food evidence only enters the record in the Acheulian. Why? Because the hominin evidence from the Oldowan consists of scattered bones that were subjected to fluvial activities of one sort or another, i.e., are not in situ.

2. The selection of favored stone types for tools, the first tools, appears in the Oldowan, an item for which the other hominids show no propensity even today.

3. Intentional burials are a hominin characteristic present at least since the Middle Palaeolithic, with earlier evidence for this practice, if it were present, having been erased by varied sedimentary activities of one type or another. Human burial practices, of course, are very, very varied from culture-to-culture.

4. Intrahuman violence appears to be an ever-present human practice with positive evidence first appearing in the Middle Palaeolithic with battered skulls.

5. Evidence of hunting, sometimes with tools, first appears in the Acheulian, but again the lack of Oldowan evidence is easily explained by post-depositional activities of one kind or another.

6. Evidence of care of the handicapped, a typically human behavior, first appears in the Middle Palaeolithic, Mousterian.

7. Personal adornments, another typically human attribute, first appears with beads in the Acheulian. This listing is by no means a complete one, only a few highlights, that indicate the quantum evolution behavioral gap between the other hominids and the hominins.

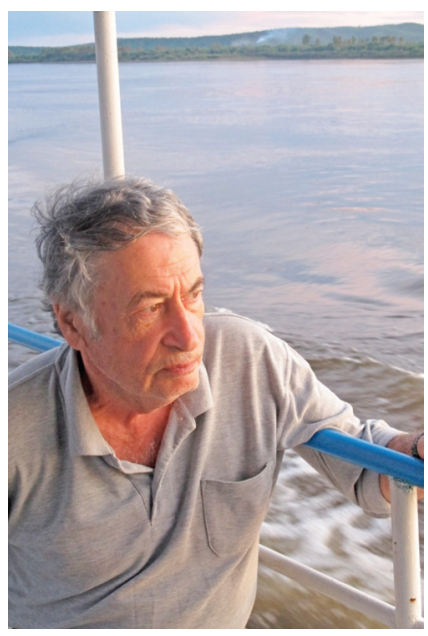

